Д. В. КОНОВАЛОВ ${ }^{1}$, Р. М. РАДЧЕНКО 1 , С. Г. ФОРДУЙ ${ }^{2}$, В. П. ХАЛДОБІН ${ }^{1}$, О. О. ЗЕЛІКОВ ${ }^{1}$, О. А. РІЗУН ${ }^{1}$

${ }^{1}$ Національний університету кораблебудування імені адмірала Макарова, Украйна

2 PepsiCo, Inc., CTS ESSA, Київ, Украӥна

\title{
ВДОСКОНАЛЕННЯ ТЕПЛОВИКОРИСТОВУЮЧИХ ЕЖЕКТОРНИХ ХОЛОДИЛЬНИХ МАШИН ЗАСТОСУВАННЯМ АЕРОТЕРМОПРЕСОРНИХ ТЕХНОЛОГІЙ
}

\begin{abstract}
В роботі показано та проаналізовано схемні рішення для вдосконалення існуючих схем ежекторних тепловикористовуючих холодильних машин, які застосовуються у складі установок комбінованого виробництва енергії. Одним з перспективних напрямків є застосування аеротермопресора, де реалізується ефект термогазодинамічної компресії, який полягає в підвищенні тиску при одночасному зниженні температури в прочесі випаровування дрібнодисперсної рідини, яка впорскується в потік пари, щуо рухається із швидкістю біля звукової. Для аналізу ефективності ежекторних холодильних машин було використано розроблену розрахункову модель, щчо враховує застосування аеротермопресора в ичиклах холодильних машин разом із особливостями розрахунків циилів і схем. Для вибору та визначення можливих схемних рішень очінювалася ефективність роботи аеротермопресора для різних холодоагентах $i$ зроблений порівняльний аналіз характерних параметрів ефективності аеротермопресора в діапазоні різниць температур охолодження 20-100 ${ }^{\circ}$ C. Збільшити ефективність ежекторної холодильної машини при застосуванні аеротермопресора можливо при забезпеченні різниці температур $60-100^{\circ} \mathrm{C}$. Аналіз показав, шуо найбільше значення підвищення теплового коефічієнта мають: R717, R134a, R227еa, R1234ze(E), $R 1234 y f(2-4 \%)$. Забезпечити більиий тепловий коефіиієнт можливо при застосування аеротермопресора в схемі із використанням ицикуляиії рідкого холодоагенту. Відповідне збільшення теплового коефіцієнта при цุьому складає 1,5-2,0\%. Застосування аеротермопресора в схемі із регенерацією теплоти дозволяє зняти додатковий перегрів пари перед всмоктуванням в ежектор з відповідним підвищення теплового коефіuієнта на 4-8\%. Аналіз показує, щзо сумарне підвищення теплового коефіиієнту за рахунок сумісного застосування аеротермопресора, регенерації теплоти та рециикуляиії складає 10-15\% при базовому значенні 0,30-0,40.
\end{abstract}

Ключові слова: утилізація теплоти; енергетична установка; аеротермопресор; ежектор; тепловикористовуюча холодильна машина.

\section{1. Аналіз проблеми і постановка мети дослідження}

Одним 3 напрямків підвищення енергетичної ефективності тепловикористовуючих ежекторних холодильних машин (ЕХM) [1-3] є застосування струминних аеротермопресорних технологій на основі ефекту термогазодинамічної компресії [4]. Ефект термогазодинамічної компресії полягає в підвищенні тиску при одночасному зниженні температури в процесі випаровування дрібнодисперсної рідини, яка впорскується в потік пари (газу), що рухається із швидкістю біля звукової.

Підвищення ефективності ЕХМ можливе в напрямках вибору раціональної схеми ЕХМ із аеротермопресором і вибору найбільш ефективного робочого тіла (холодоагенту).
Мета дослідження - аналіз способів вдосконалення тепловикористовуючих ежекторних холодильних машин застосуванням аеротермопресорів.

\section{2. Результати дослідження}

Розроблений програмний комплекс, який дозволяє визначити параметри робочого тіла (холодоагенту) в характерних точках циклу, параметри термодинамічної ефективності ЕХМ, параметри і конструктивні характеристики аеротермопресора.

Розрахунок напірно-циркуляційних характеристик ежектора зводиться до визначення його досяжного коефіцієнта ежекції U. Найбільш розповсюдженою та загальноприйнятою методикою розрахунку цих характеристик $є$ методика, запропонована [1]. Газодинамічні функції розраховуються за загальноприйнятими залежностями [2]. 
При аналізі схемо-технічних рішень підвищення ефективності ЕХМ розглянута відома класична схема ЕХМ (рис. 1). Ефективність застосування аеротермопресора визначалася за наступними основними параметрами: відносне $\left(\mathrm{P}_{\mathrm{c} 2} / \mathrm{P}_{\mathrm{c} 1}\right)$ та абсолютне $\Delta \mathrm{P}_{\mathrm{c}}$ підвищення тиску; відносне $\left(\mathrm{T}_{\mathrm{c} 1} / \mathrm{T}_{\mathrm{c} 2}\right)$ та абсолютне $\Delta \mathrm{T}_{\mathrm{c}}$ зменшення температури газового потоку; відносна кількість рідини, що вприскується в аеротермопресор для повного випаровування $\mathrm{g}_{\mathrm{f}}$. Ефективність циклу ЕХМ з і без аеротермопресора здійснювалася за коефіцієнтом ежекції U, як основного показника ефективності ежектора ЕXM, та за тепловим коефіцієнтом $\zeta$.

Аналіз ефективності циклу ЕХМ здійснювався за наступних умов:

- температура конденсації $-\mathrm{t}_{\mathrm{c}}=35^{\circ} \mathrm{C}$;

- температура кипіння у випарнику ЕХМ $\mathrm{t}_{0}=5 \mathrm{i} 10^{\circ} \mathrm{C}$;

- температура кипіння в генераторі пари $\mathrm{t}_{\mathrm{g}}=60-140{ }^{\circ} \mathrm{C}$.

Одним з варіантів зниження тиску пари на виході з дифузору ежектора ЕХМ при незмінній температурі конденсації $t_{c} \in$ застосування аеротермопресора перед конденсатором (рис. 1). У робочу камеру аеротермопресора вприскується рідина, що відбирається 3 нагнітання циркуляційного насоса. Загальна холодопродуктивність $\mathrm{Q}_{0} \mathrm{EXM}$ не змінюється за рахунок збільшення кількості робочого тіла $\mathrm{g}_{\mathrm{f}}$ (холодоагенту), що циркулює в контурі ЕХМ. Зниження перегріву пари в аеротермопресорі дозволяє також зменшити теплове навантаження на конденсатор і тим самим скоротити витрату охолоджуючої води (або повітря) конденсатора.

Збільшення повного тиску перед конденсатором забезпечить зменшення степені підвищення тиску в ежекторі ЕХМ і, як наслідок, збільшення коефіцієнта ежекції U і теплового коефіцієнта ЕХМ $\zeta$ або при не змінних степені підвищення тиску в ежекторі, U i $\zeta$ дозволить зменшити температуру кипіння холодоагенту в випарнику $\mathrm{t}_{0}$.

Подача рідкого холодоагенту здійснюється при відбиранні за циркуляційним насосом. Таке рішення дозволяє забезпечити більш високий тиск на вприскуванні форсунки аеротермопресора, а відтак, зменшити середній діаметр крапель рідини на вході в робочу камеру проточної частини, що, у свою чергу, збільшить загальний приріст тиску в аеротермопресорі за рахунок зменшення відносної довжини випаровування, а також зменшення впливу лобового опору краплі в паровому потоці. Температура крапель, що упорскуються, буде близькою до температури насичення потоку, що також позитивно впливає на зменшення або повне виключення режиму в проточній частині аеротермопресора, де переважає лобовий опір крапель (початкова ділянка робочої камери).

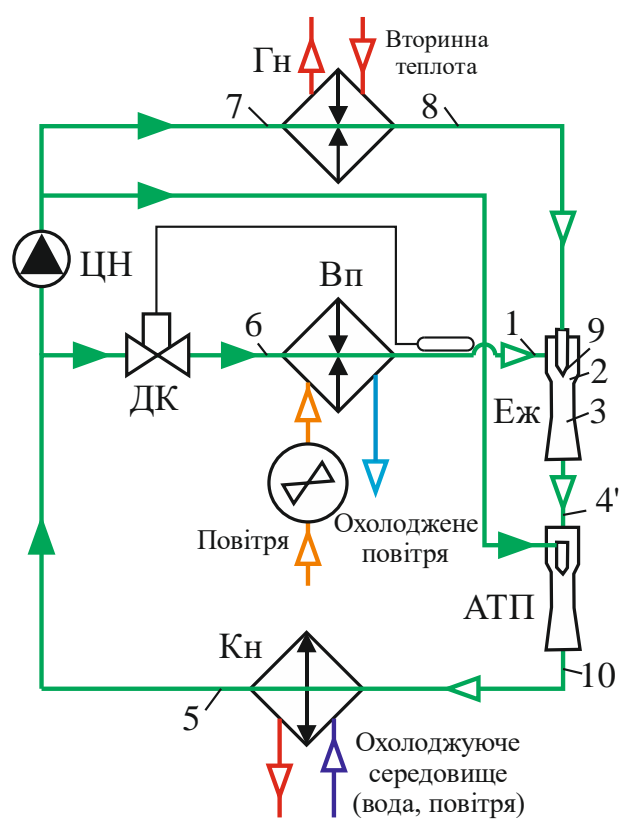

a)

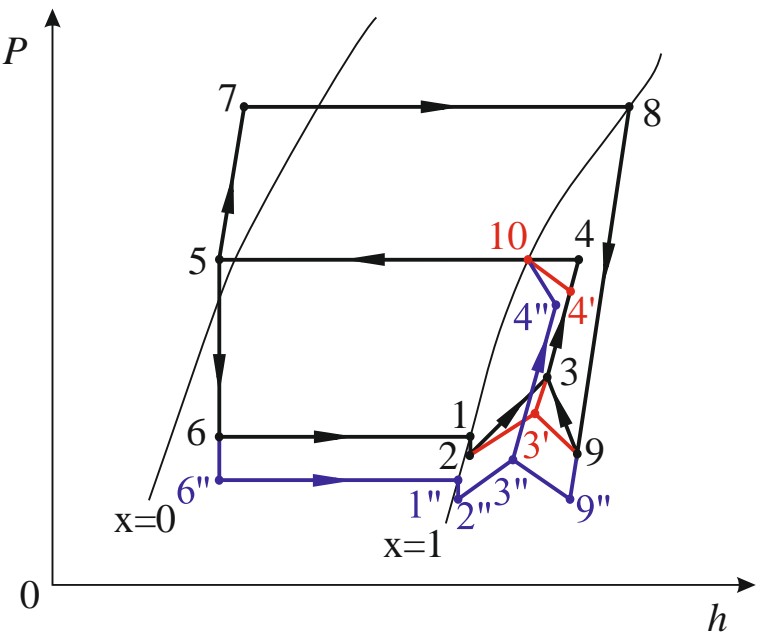

б)

Рис. 1. Схема (а) та цикл (б) ЕХМ із застосуванням аеротермопресора: АТП - аеротермопресор;

Еж - ежектор; Кн - конденсатор; ВП - випарник;

ДК - дросельний клапан; Цн - циркуляційний насос; Гн - генератор; 1-2-3-4-5-6-7-8-9 - цикл ЕХМ

без аеротермопресора; 1-2-3'-4'-10-5-6-7-8-9 - цикл

ЕХМ 3 аеротермопресором;

1"-2"-3"-4"-10-5-6"-7-8-9" - цикл ЕХМ 3 аеротермопресором

(зниження температури кипіння $\mathrm{t}_{0}$ у випарнику)

Збільшення тиску в аеротермопресорі дозволяє зменшити степінь стиснення в ежекторі ЕXM, а звідси збільшити коефіцієнт ежекції. Аналіз ефективності робочого процесу аеротермопресора показує, що позитивне збільшення тиску парового потоку (рис. 2 і 3) буде спостерігатися лише для де-яких хо- 
лодоагентів. В інших випадках для холодоагентів характерно зменшення повного тиску в наслідок переважаючого впливу опору при невеликих перепадах температур в аеротермопресорі.

Незначні показники теплових коефіцієнтів ЕХМ можна пояснити невеликою різницею температури $\Delta \mathrm{T}_{\mathrm{c}}$ при охолодженні потоку в аеротермопресорі. Звідси можна зробити висновок про необхідність застосування аеротермопресора і в інших можливих схемах EXM. В таких схемах охолодження пари холодоагенту повинно бути більшою ніж $\Delta \mathrm{T}_{\mathrm{c}}=30-40^{\circ} \mathrm{C}$.

Для вибору та визначення можливих схемних рішень при застосуванні аеротермопресора в схемах ЕХМ необхідно оцінити ефективність роботи аеротермопресора при різних холодоагентах і в більшому діапазоні охолодження парового потоку. Зроблений порівняльний аналіз характерних параметрів ефективності аеротермопресора для ряду холодоагентів в діапазоні температур охолодження $\Delta \mathrm{T}_{\text {atp }}=20-100{ }^{\circ} \mathrm{C}$ (відносна температура $\left.\left(\mathrm{T}_{\text {atp } 1} / \mathrm{T}_{\text {atp2 }}\right)=1,05-1,35\right)$ показав наступне. При різниці температур $\Delta \mathrm{T}_{\text {атп }}=60-100{ }^{\circ} \mathrm{C}$ відносне підвищення тиску для всіх холодоагентів позитивне (рис. 2 і 3 ).

Найбільше значення мають:

- R717 (аміак) - $\left(\mathrm{P}_{\text {atp2 }} / \mathrm{P}_{\text {atp } 1}\right)=1,0393\left(0,5848 \cdot 10^{5}\right.$ Па); $\mathrm{R} 134 \mathrm{a}-\left(\mathrm{P}_{\text {atp2 }} / \mathrm{P}_{\text {atp } 1}\right)=1,0295\left(0,4331 \cdot 10^{5} \Pi \mathrm{a}\right)$;

- R227ea - $\left(\mathrm{P}_{\text {atp2 }} / \mathrm{P}_{\text {atp1 }}\right)=1,0224\left(0,2831 \cdot 10^{5}\right.$ Пa $)$;

- R1234ze $(\mathrm{E})-\left(\mathrm{P}_{\text {atp } 2} / \mathrm{P}_{\text {atp } 1}\right)=1,0210\left(0,2713 \cdot 10^{5}\right.$ Па);

- R1234yf $-\left(\mathrm{P}_{\text {atp } 2} / \mathrm{P}_{\text {atp } 1}\right)=1,0280\left(0,25 \cdot 10^{5}\right.$ Па $)$;

- для холодоагентів R142b, R245fa, R600 підвищення тиску навіть при більших температурах в генераторі невелике $-\left(\mathrm{P}_{\text {atp } 2} / \mathrm{P}_{\text {atp1 }}\right)=1,005-1,011(0,10$ $0,12 \cdot 10^{5} \Pi$ ).

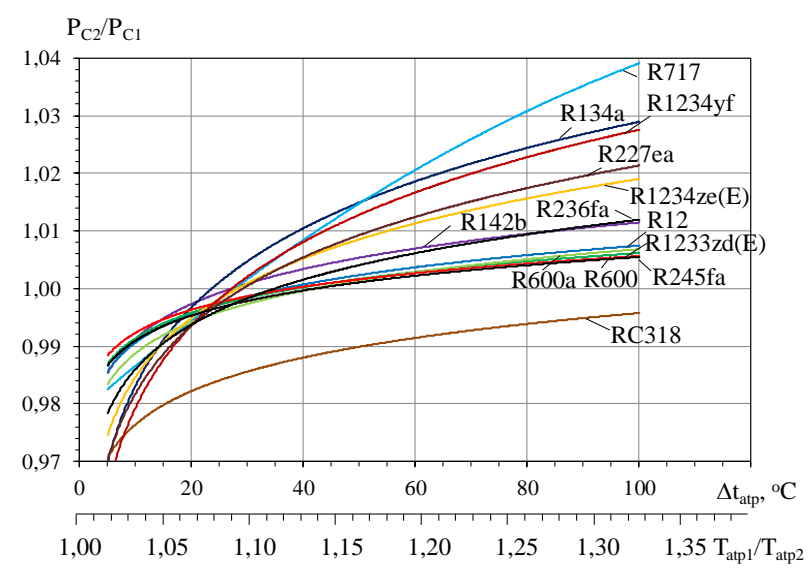

Рис. 2. Залежності зміни відносного підвищення тиску аеротермопресора $\left(\mathrm{P}_{\mathrm{c} 2} / \mathrm{P}_{\mathrm{c} 1}\right)$ від зменшення температури пари $\Delta \mathrm{T}_{\text {atp }}$ і відносної температури

$\left(\mathrm{T}_{\text {atp }} / \mathrm{T}_{\text {atp2 }}\right)$ в аеротермопресорі для різних холодоагентів
Відносна кількість (рис. 4), необхідної для повного випаровування, рідини складає в середньому $\mathrm{g}_{\mathrm{f}}=0,2-0,9$ (20-90\%). Більші витрати рідини характерні для більшої різниці температур в аеротермопресорі. Найбільша витрата рідина відповідає холодоагентам R1234yf, R134a, R227ea (біля 80-90\%).

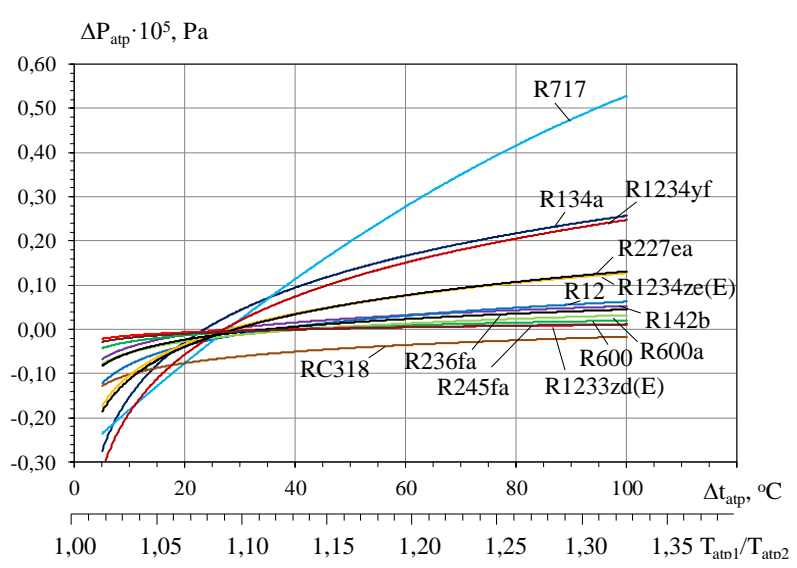

Рис. 3. Залежності зміни повного тиску аеротермопресора $\Delta \mathrm{P}_{\text {atp }}$ від зменшення температури пари $\Delta \mathrm{T}_{\text {atp }}$ i відносної температури $\left(\mathrm{T}_{\text {atp } 1} / \mathrm{T}_{\text {atp2 }}\right)$ в аеротермопресорі для різних холодоагентів

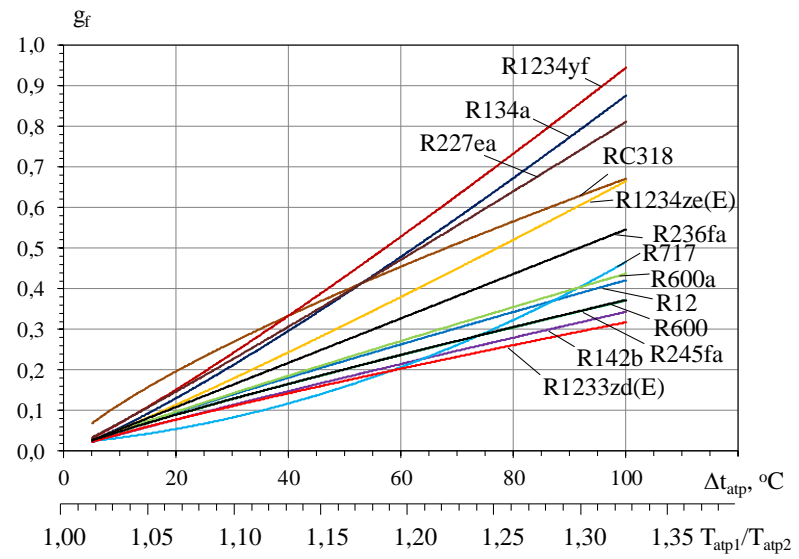

Рис. 4. Залежності зміни відносної кількості рідини $\mathrm{g}_{\mathrm{f}}$, що вприскується для повного випаровування в аеротермопресорі від зменшення температури пари $\Delta \mathrm{T}_{\text {atp }}$ i відносної температури $\left(\mathrm{T}_{\text {atp }} / \mathrm{T}_{\text {atp2 }}\right)$ для різних холодоагентів.

Для забезпечення більших приростів теплового коефіцієнта $\zeta$ необхідна більша різниця температур в аеротермопресорі, а відтак, і буде більшим підвищення відносного тиску в аеротермопресорі $\left(\mathrm{P}_{\mathrm{atp} 2} / \mathrm{P}_{\mathrm{atp} 1}\right)$.

Перспективним рішенням $є$ застосування аеротермопресора в схемі із регенерацією теплоти в регенеративному теплообміннику (РТО) (рис. 5). При 
цьому аеротермопресор доцільно встановити за випарником на всмоктуванні в ежектор. Відомо, що перегрів пари на всмоктуванні ежектора негативно впливає на значення коефіцієнта ежекції U [3]. Таке рішення дозволить зняти додатковий перегрів пари перед всмоктуванням в ежектор (в цьому випадку підвищення тиску $\left(\mathrm{P}_{\text {atp } 2} / \mathrm{P}_{\text {atp } 1}\right)$ в аеротермопресорі не буде), а відтак, забезпечить підвищення теплового коефіцієнта на $\zeta=2-5 \%$.

Підвищити тиск на всмоктуванні в ежектор і за рахунок цього прибрати перегрів пари після РТО в EXM з регенерацією теплоти можна шляхом включення аеротермопресора на всмоктуванні в ежектор (після випарника) із одночасним забезпеченням неповного випаровування холодоагенту і інжекцією рідини (рис. 5). Результати розрахунків при температуpax кипіння у випарнику $\mathrm{t}_{0}=-10 \ldots+20{ }^{\circ} \mathrm{C}$ показують, що тільки при перегрівах після РТО $\Delta \mathrm{t}_{\text {пер }}=100-140$ ${ }^{\circ} \mathrm{C}$ можливе збільшення теплового коефіцієнта ЕХМ

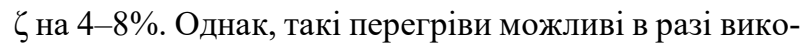
ристання додаткових джерел скидної теплоти.

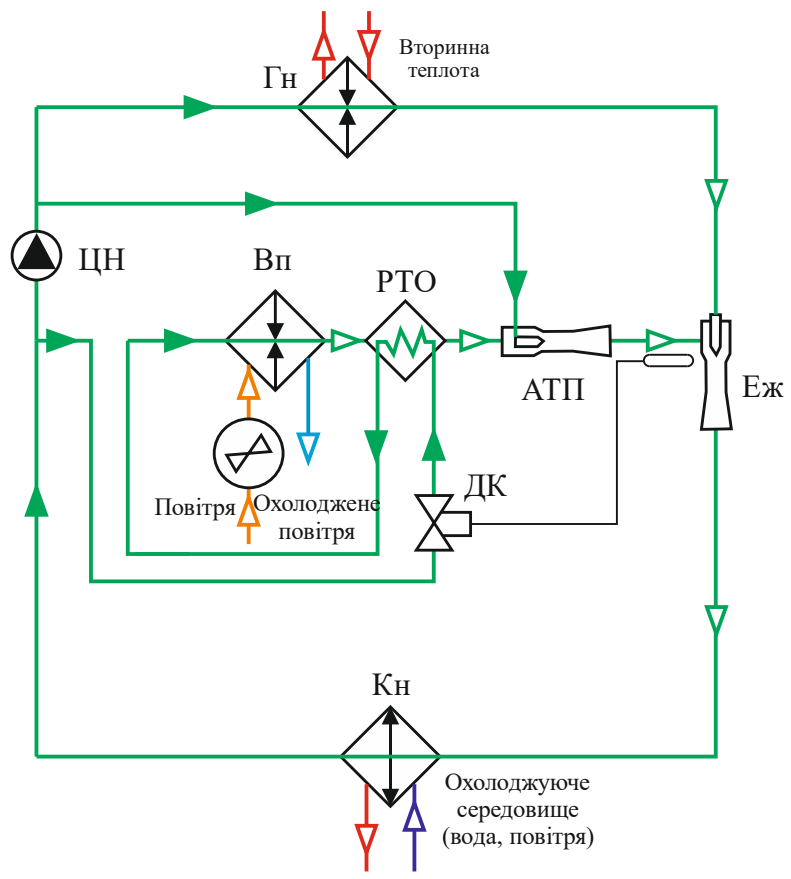

Рис. 5. Схема регенеративної ЕХМ із сумісним застосуванням аеротермопресора і інжектора:

АТП - аеротермопресор; Еж - ежектор;

Вп - випарник; Кн - конденсатор;

Гн - генератор пари; Цн - циркуляційний насос; РТО - регенеративний теплообмінник

Підвищити тиск на всмоктуванні в ежектор і при цьому зняти перегрів після РТО ЕХМ можливо за рахунок включення в схему установки аеротермопресора АТП (рис. 6, а). Установка працює в такий спосіб: ежектор ЕЖ всмоктує пар з випарника ВП, використовуючи енергію робочого пара високого тиску (точка 10 на рис. 6, б), який надходить з генератора Гн, розширюється в його соплі до тиску (точка 11), трохи меншого, ніж тиск пари на виході з РТО (точка 1), і стискає його до тиску конденсації (точка 4); Процеси 9-10 і 7-8 - кипіння (можливо з перегрівом) в випарнику і генераторі робочого пара високого тиску; 10-11 - розширення робочого пара в соплі ежектора; 1-2 - зниження тиску всмоктується з РТО пара в приймальній камері ежектора; 2-3 і 11-3 - змішання холодного пара з випарника і пара на виході з сопла ежектора; 3-4 - підвищення тиску змішаного пара в камері змішання і дифузорі ежектора.

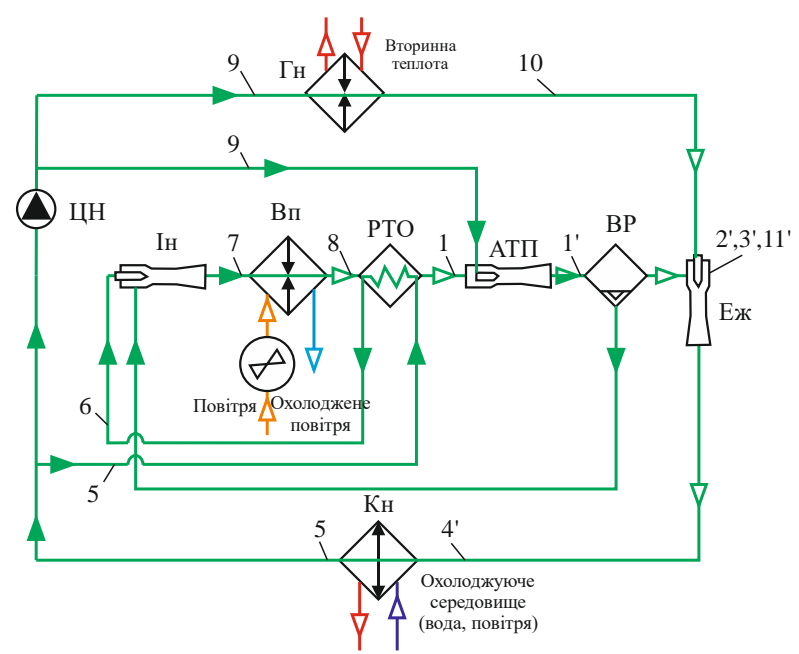

a)

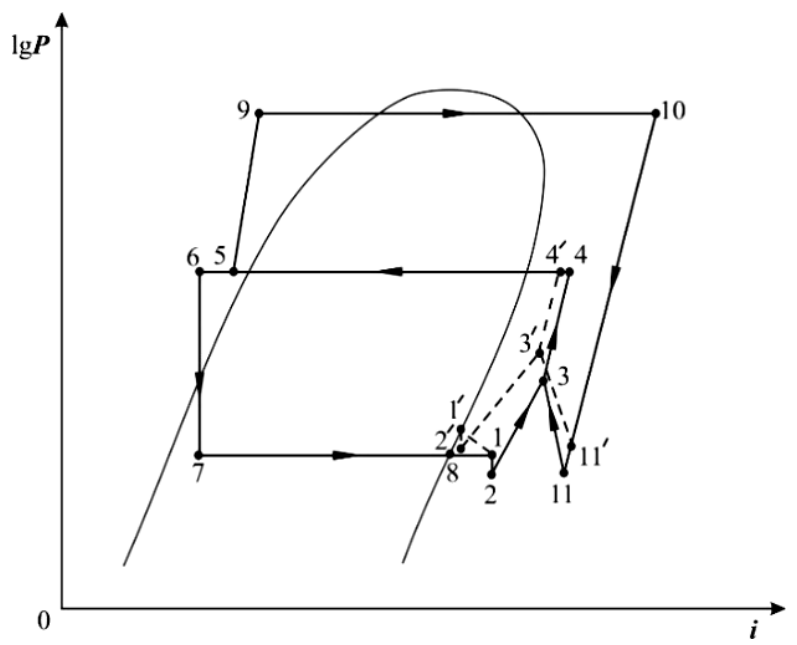

б)

Рис. 6. Схема і цикл ЕХМ із застосуванням аеротермопресора в комбінації з ежектором:

Гн - генератор пари; Еж - ежектор;

АТП - аеротермопресор; Кн - конденсатор; Вп - випарник; Ін - інжектор;

РТО - регенеративний теплообмінник; ВР - віддільник рідини; ЦН - циркуляційний насос;

- - - - - цикл ЕXМ із аеротермопресором; - цикл ЕХМ без аеротермопресора 
Стиснутий в ежекторі ЕЖ пар конденсується в конденсаторі Кн (процес 4-5). Рідкий холодоагент розділяться на два потоки. Перший надходить в РТО, де переохолоджується за рахунок пара після випарника Вп (процес 5-6) і дроселюється в інжекторі Ін (процес 6-7) потім випаровується у випарнику (процес 7-8) i отриманий насичений пар перегрівається в РТО (процес 8 -1). Другий потік - стискається в насосі ЦН до високого тиску (процес 5-9) і випаровується в генераторі Гн (процес 9-10).

Аеротермопресор встановлюється на всмоктуванні в ежектор після РТО. Для зняття перегріву і підвищення тиску потоку пара після РТО в робочу камеру в аеротермопресора вприскується частина рідини після циркуляційного насоса. Вприскування необхідно здійснювати в потік пари, що рухається із навколозвуковою швидкістю.

Аналіз роботи установки (рис. 7) при температурах кипіння у випарнику, показує, що при перегріві пари після РТО $\Delta \mathrm{t}_{\text {пер }}=100-140{ }^{\circ} \mathrm{C}$ збільшення теплового коефіцієнта ЕХМ на додаток до ефекту від регенерації складе $\Delta \zeta=4-8 \%$, із відповідною часткою рідини, що вприскується $\mathrm{g}=0,05-0,25$, при цьому сумарне підвищення теплового коефіцієнту складає $\Delta \zeta=10-15 \%(\zeta=0,03-0,05)$, при базовому значенні $\zeta=0,30-0,40$.

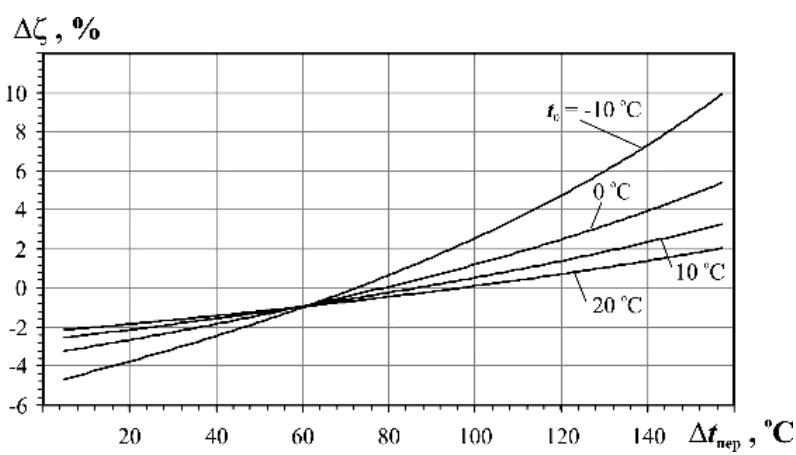

Рис. 7. Залежності збільшення теплового коефіцієнта $\Delta \zeta$ для R134а від температури перегріву $\Delta \mathrm{t}_{\text {пер }}$ при різних температурах кипіння $\mathrm{t}_{0}$

\section{Висновки}

1. Збільшити ефективність ЕХМ при застосуванні аеротермопресора можливо при забезпеченні більшої різниці температур в проточній частині. Так, при різниці температур $\Delta \mathrm{T}_{\text {atp }}=60-100{ }^{\circ} \mathrm{C}$ найбільше значення мають: R717, R134a, R227ea, R1234ze(E), $\mathrm{R} 1234 \mathrm{yf}-\left(\mathrm{P}_{\text {atp2 }} / \mathrm{P}_{\text {atp1 }}\right)=1,02-1,04(2-4 \%)$.

2. Застосування термопресора в схемі із регенерацією теплоти за випарником на всмоктуванні в ежектор дозволяє зняти додатковий перегрів пари перед всмоктуванням в ежектор, а відтак, забезпечить підвищення теплового коефіцієнта на $\Delta \zeta=4-8 \%$, iз відповідною часткою рідини, що вприскується $\mathrm{g}=0,05-0,25$ (5-25\%), при цьому сумарне підвищення теплового коефіцієнту за рахунок регенерації теплоти та рециркуляції при сумісному застосуванні iз аеротермопресором складає $\Delta \zeta=10-15 \%$ при базовому значенні $\Delta \zeta=0,30-0,40$.

\section{Література}

1. Experimental investigation and theoretical analysis of an ejector refrigeration system [Text] / D. A. Pounds, J. M. Dong, P. Cheng, H. B. Ma // International Journal of Thermal Sciences. - 2013. - Vol. 67. - P. 200 209.

2. Chen, J. Y. Investigation of ejector in refrigeration systems: optimum performance evaluation and ejector area ratios perspectives [Text] / J. Y. Chen, H. Havtun, B. Palm // Applied Thermal Engineering. - 2014. Vol. 64. - P. 182-191.

3. Investigation of an experimental ejector refrigeration machine operating with refrigerant $R 245$ fa at design and off-design working conditions [Text] / K. O. Shestopalov, B. J. Huang, V. O. Petrenko, O. S. Volovyk // International Journal of Refrigeration. - 2015. Vol. 55. - P. 212-223.

4. Research of the Aerothermopressor Cooling System of Charge Air of a Marine Internal Combustion Engine Under Variable Climatic Conditions of Operation [Text] / D. Konovalov, E. Trushliakov, M. Radchenko, H. Kobalava, V. Maksymov ; In: Tonkonogyi V. et al. (eds.) Advanced Manufacturing Processes. InterPartner 2019. Lecture Notes in Mechanical Engineering. - 2020. - P. 520-529.

\section{References}

1. Pounds, D. A., Dong, J. M., Cheng, P., Ma, H. B. Experimental investigation and theoretical analysis of an ejector refrigeration system. International Journal of Thermal Sciences, 2013, vol. 67, pp. 200-209.

2. Chen, J. Y., Havtun, H., Palm, B. Investigation of ejector in refrigeration systems: optimum performance evaluation and ejector area ratios perspectives. Applied Thermal Engineering, 2014, vol. 64, pp. 182-191.

3. Shestopalov, K. O., Huang, B. J., Petrenko, V. O., Volovyk, O. S. Investigation of an experimental ejector refrigeration machine operating with refrigerant $\mathrm{R} 245 \mathrm{fa}$ at design and off-design working conditions. International Journal of Refrigeration, 2015, vol. 55, pp. 212223.

4. Konovalov, D., Trushliakov, E., Radchenko, M., Kobalava, H., Maksymov, V. Research of the Aerothermopressor Cooling System of Charge Air of a Marine Internal Combustion Engine Under Variable Climatic Conditions of Operation. In: Tonkonogyi V. et al. (eds.) Advanced Manufacturing Processes, InterPartner 2019, Lecture Notes in Mechanical Engineering, 2020, pp. 520-529. 


\title{
СОВЕРШЕНСТВОВАНИЕ ТЕПЛОИСПОЛЬЗУЮЩИХ ЭЖЕКТОРНЫХ ХОЛОДИЛЬНЫХ МАШИН ПРИМЕНЕНИЕМ АЕРОТЕРМОПРЕСОРНИХ ТЕХНОЛОГИЙ
}

\author{
Д. В. Коновалов, Р. Н. Радченко, С. Г. Фордуй, В. П. Халдобин, А. О. Зеликов, А. А. Ризун
}

В работе показано и проанализированы схемные решения для совершенствования существующих схем эжекторных теплоиспользующих холодильных машин, которые применяются в составе установок комбинированного производства энергии. Одним из перспективных направлений является применение аеротермопресора, где реализуется эффект термогазодинамических компрессии, который заключается в повышении давления при одновременном снижении температуры в процессе испарения мелкодисперсной жидкости, впрыскивается в поток пара, движущегося со скоростью около звуковой. Для анализа эффективности эжекторных холодильных машин было использовано разработанную расчетную модель, учитывающая применения аеротермопресора в циклах холодильных машин с учетом особенностей расчетов циклов и схем. Для выбора и определения возможных схемных решений оценивалась эффективность работы аеротермопресора на различных хладагентах и сделан сравнительный анализ характерных параметров эффективности аеротермопресора в диапазоне разниц температур охлаждения $20-100{ }^{\circ} \mathrm{C}$. Увеличить эффективность ЭХМ при применении аэротермопрессора возможно при обеспечении разницы температур $60-100{ }^{\circ} \mathrm{C}$. Анализ показал, что наибольшее значение имеют: R717, R134a, R227ea, R1234ze (E), R1234yf (2-4\%). Обеспечить больший тепловой коэффициент для ЭХМ возможно при применении аеротермопресора в схеме с использованием циркуляции жидкого холодоагента. Соответствующее увеличение теплового коэффициента при этом составляет 1,5-2,0\%. Применение аэротермопрессора в схеме с регенерацией теплоты позволяет снять дополнительный перегрев пара перед всасыванием в эжектор с соответствующим повышение теплового коэффициента на 4-8\%. Анализ показывает, что суммарное повышение теплового коэффициента за счет совместного применения аеротермопресора, регенерации теплоты и рециркуляции составляет 10-15\% при базовом значении 0,30-0,40.

Ключевые слова: утилизация теплоты; энергетическая установка; аеротермопресор; эжектор; теплоиспользующая холодильная машина.

\section{IMPROVEMENT OF HEAT USE EJECTOR REFRIGERATORS BY USING AEROTHERMOPRESSOR TECHNOLOGIES}

\section{Konovalov, R. Radchenko, S. Forduy, V. Khaldobin, O. Zielikov, O. Rizun}

The paper shows and analyzes circuit solutions for improving the existing schemes of ejector heat-using refrigeration machines, which are used as part of cogeneration plants. One of the promising areas is the use of an aerothermopressor, which implements the effect of thermogasdynamic compression, which is to increase the pressure while reducing the temperature in the evaporation of liquid, which injected into the flow of vapor moving at speed near the sound. To analyze the efficiency of ejector refrigeration machines, the developed calculation model was used, which takes into account the use of an aerothermopressor in the cycles of refrigeration machines with the features of the calculations of cycles and circuits. To select and determine possible circuit solutions, the efficiency of an aerothermopressor for different refrigerants was evaluated and a comparative analysis of the characteristic parameters of the efficiency of an aerothermopressor in the range of cooling temperature differences is $20-100{ }^{\circ} \mathrm{C}$ was made. It is possible to increase the efficiency of ejector heat-using refrigeration machines when using an aerothermopressor by providing a temperature difference of $60-100{ }^{\circ} \mathrm{C}$. The analysis showed that the most important are: R717, R134a, R227ea, R1234ze (E), R1234yf (2-4\%). It is possible to provide a higher thermal coefficient for ejector heat-using refrigeration machines by using an aerothermopressor in the circuit using the circulation of liquid refrigerant. The corresponding increase in the thermal coefficient is $1.5-2.0 \%$. The use of an aerothermopressor in the scheme with heat recovery allows removing additional overheating of vapor before suctioning into the ejector with a corresponding increase in the thermal coefficient by $4-8 \%$. The analysis shows that the total increase in the thermal coefficient due to the combined use of an aerothermopressor, heat recovery, and recirculation is $10-15 \%$ at a base value of $0.30-0.40$.

Keywords: heat utilization; power plant; aerothermopressor; ejector; heat-using refrigeration machine. 
Коновалов Дмитро Вікторович - канд. техн. наук, зав. кафедри теплотехніки, Херсонська філія Національного університету кораблебудування імені адмірала Макарова, Херсон, Україна.

Радченко Роман Миколайович - канд. техн. наук, доц., Національний університет кораблебудування імені адмірала Макарова, Миколаїв, Україна.

Фордуй Сергій Георгійович - канд. техн. наук, технічний керівник напряму енергоресурсів та енергозбереження РеpsiCo, Inc., CTS ESSA, Київ, Україна.

Халдобін Віктор Павлович - аспірант кафедри кондиціювання та рефрижерації, Національний університет кораблебудування імені адмірала Макарова, Миколаїв, Україна.

Зєліков Олексій Олегович - аспірант кафедри кондиціювання та рефрижерації, Національний університет кораблебудування імені адмірала Макарова, Миколаїв, Україна.

Різун Олександр Анатолійович - аспірант кафедри кондиціювання та рефрижерації, Національний університет кораблебудування імені адмірала Макарова, Миколаїв, Україна.

Dmytro Konovalov - Candidate of Technical Science $(\mathrm{PhD})$, Head of Thermal Engineering department, The Kherson Branch of Admiral Makarov National University of Shipbuilding, Kherson, Ukraine, e-mail: dimitriyko79@gmail.com, ORCID: 0000-0001-7127-0487

Roman Radchenko - Candidate of Technical Science, Associate professor, Admiral Makarov National University of Shipbuilding, Mykolaiv, Ukraine,

e-mail: nirad50@gmail.com, ORCID: 0000-0003-2211-3500

Serhiy Forduy - Candidate of Technical Science, Sr. Engineering manager PepsiCo, Inc., Central Technical Team-Europe and Sub Saharan Africa (CTS ESSA), Kyiv, Ukraine, e-mail: serhiy.forduy@pepsico.com, ORCID: 0000-0003-0110-4090

Viktor Khaldobin - PhD student of Conditioning and Refrigeration Department of Admiral Makarov National University of Shipbuilding, Mykolaiv, Ukraine, e-mail: mr.khaldobin@inbox.lv, ORCID: 0000-0002-0498-4401

Oleksii Zielikov - PhD student of Conditioning and Refrigeration Department of Admiral Makarov National University of Shipbuilding, Mykolaiv, Ukraine, e-mail: Kolohort@gmail.com, ORCID: 0000-0001-8051-6063

Oleksandr Rizun - PhD student of Conditioning and Refrigeration Department of Admiral Makarov National University of Shipbuilding, Mykolaiv, Ukraine, e-mail: rizunksm@gmail.com, ORCID: 0000-0002-1625-959X 